\title{
On College English Teaching and Cultivation of Sense of Culture and Affection for College Students
}

\author{
Hui Wu ${ }^{1, a}$ \\ ${ }^{1}$ Hubei Engineering University \\ ${ }^{a}$ E-mail: 443138446@qq.com
}

Key words: College English; Culture; Affection; Class

\begin{abstract}
With the increasing passion for English learning, various problems and doubts towards college English teaching arise, which has covered higher education throughout China. The main problems existing in college English teaching are the vague recognition of teaching targets, inappropriate understanding of teaching material and westernization of class. To tackle the problems, college English teachers should enhance the quality of humanities constantly, introduce the culture of China in the article explanation based on the text content, cultivate students' affection towards country and sense of nation and turn the class into a real place.
\end{abstract}

\section{Introduction}

College English education has permeated every college throughout China since it's set as the fundamental course for college students in Grade 1 and 2. With the development of economic globalization , social requirements for English standard has got more and more demanding, which has led to the hot situation of English study. Therefore, English learning has become such an important part of college study that it may have some impact on students' growth and life.

Since the enforcement of open and reform policy, the increasing enthusiasm for English study has attracted attention of expects in different fields, which has sparked hot discussion in society. Some scholars believe this trend is not favorable for our traditional culture because they are afraid of the conquer of western liberalism that may have bad impact on the development and stability of China. On the contrary, other experts think it's a must process China integrates into the world, and learning English should be encouraged. The arguing of two voices has never ceased. Hence, it's urgent to put College English Education into a proper position and guide it appropriately in modern society.

\section{The Current Situation and Problems of College English Education}

Being a compulsive course, the certificate of CET4 and CET6 has been connected with students graduation and general acceptance of English performance, which have caused students' full passion for studying English. Some students are even more passionate at learning English than Chinese. Some students learn it for a good job after graduation; some for diploma with CET4 or 6; some for further postgraduate entrance examination; and others for further study abroad.

College English education features some qualities. First, it is different from the fundamental English teaching. The content of English learning for Middle school and college is different, as well as the arrangements of teaching material. Standard for English Course of Senior Middle School published by Education Department has set the principle that the purpose of Middle School English teaching is to cultivate the students' comprehensive language performance ability, which focuses on language points in the arrangements of teaching material. However, Requirements of College English Teaching set by Higher Branch of Education Department claim that the purpose of college English education is to develop the comprehensive English application ability, especially the ability of speaking and listening, which could help them to conduct the effective oral and written English communication. The content of the teaching material for college English teaching is colorful that has got involved the western society and culture. Second, which is the prior task for college English teachers, teaching language points or cultivating people? Being adults, students have some common sense of social knowledge and English level. College English teachers are faced with students who 
are like a paper with some pictures, the complement of the picture is determined by the teachers' work. Some teachers believe that the prior task for college English teacher is to pass the language knowledge . In their opinion, language class is a for language points learning. They ignored the cultivation of good personalities and moral principles, which have been taken as the main task of "cultivating people" in college education. Finally, As the development of national college English teaching reform, many colleges pay more attention to pursue the quality of college English teaching based on the ratio of passing CET-4, neglecting the general purpose of college English education. It has changed the English course into a course for CET test that's not favorable for the ultimate goal of college English teaching and cultivating formula of higher education[1]. The Higher Education Law of the People's Republic of China defines: Higher education must adhere to national's education principles, and serve for the modernization of our society, combining with producing and laboring and educating them into the qualified constructor for socialism with full development in moral ,intellectual and physical aspects. The divesefied content of college English teaching material is different from the fundamental English teaching material. The focus of the fundamental English is on the word, grammar and sentence patterns; however, the college English teaching content is colorful, involving many aspects of western society and culture like a miniature and kaleidoscope of western society.

The objective analysis and understanding of the content and introduction of western culture are the main tasks faced the college English teachers. The misunderstanding of the text may misguide the students. Due to the inappropriate analysis and understanding of the text provided by the teacher, the students' language learning just stay on the same level without improvement. The college English class is an empty class without all-rounded views on the article.

General, the main problem is the teacher's vague understanding of the subject, inappropriate explanation of the content and the unclear purpose of English learning of students.

\section{College English Education and Students Affection Cultivation}

English education is to promote the humanistic sprite. To cultivate the students to realize their self worth, it's to encourage them to pursue the ideal personality and adhere to the truth. English education is to cultivate qualified citizen,exploiting students' personality, potential ability.To promote the development of people, teachers need to pay more attention to students' affection cultivation. The element of affection in the second language acquisition is decisive, and the failure of language learning originates from the sorts of affection barrier[2]. In modern foreign language teaching, the teachers' attention for students and the cultivation of students' affection can have a good impact on their language study.

In the preface of the New Horizon college English, the editor claim that the purpose of college English teaching is to "culitvate the comprhensive applicaitonability ,especially the ability of listening and speaking, forcing them to conduct the effective communication in English , at the same time to strengthen the ability of self-study, enhancing the comprehensive cultural quality that can help them understand various cultures and be more talented[3].

The teaching material has introduced the western and social life from every aspect, covering language points and social life. The profound cultural knowledge is the basis for fantastic article explanation in the class.Thus, the comparison teaching of culture can be considered in college English class.

In the text Where Principles Come First of Book Three, there is a general introduction of American education system that sounds to be different from Chinese. In the class explanation, teachers should provide correct guidance for the students on appropriate understanding of western education. Some details in the text have conveyed the information that moral education is the first one and good personality is important for students development. From the analysis, it's obvious that discipline education has been received enough attention either in the west or in the east. No matter what country you are in, good personality is the one that bring success to you and be appreciated. Despite the different educational systems, Chinese and American educational systems have something in common. Teachers can extend the text content further to stress the basic moral rules 
are the same in all the countries and good qualities are admitted everywhere. The teacher can combine the great figure's story in Chinese history with the introduction of principles taken by Hide School to make the class interesting and impressive.

In the Olympic Standard for love of Book Two, an article of coach and athlete has been presented to the students.This is a story of love and gratitude.The stern coach has taught the athlete to be grateful for everything facing the challenges. As society develop quickly,a positive attitude towards life is very significant for so much pressure confront college students. And some students got depressed and anxious for the fierce competition on campus and in the society. Its wise for the teacher to interpret the text with examples from the society, guiding them to deal with the pressure from life with gratitude.

Some inspiring stories have been selected into the book, such as the Charlie Chaplin of Book Four. Students read the life's introduction of the famous comedian, touching by his efforts in acting and his perseverance in arts. The teacher could introduce the golden films acted by Chaplin as well as the western society and its development.Furthermore, the explanation with Chines film development could make the class more attracting and effective, for the students'interest could be stimulated .Once the interest has been sparked, it could enhance the students interest in learning with more positiveness, initialness and innovation.[4]

\section{College English Education and Cultivation of National Culture Consciousness}

It has been said that the process of education is essentially the process of cultural judgment and selection, inheritance and innovation[5].English class is the class for culture,culture is the property of human minds. "As a symbol system, language is a kind of culture. On the other hand, language reflects the people's understanding and attitude toward the objective world, accounting the national and social development."[6]. It would misguide students that the western culture is perfect with simple introduction in the process of language points teaching. Therefore, the effective and feasible language teaching is to combine western and eastern culture to make the class vivid and interesting. That's helpful for the teaching and beneficial for the cultivation of students national consciousness.

As in the As His Name Is, the teacher can open the class with the introduction of Chines name. The importance of name has been attached to new-born baby in China because name may influence his personality and life.The great work Run Tu written by Lun Xun has reflected the custom profoundly based on the story of a poor farmer whose name has been carefully selected by his parents.In the teaching process, the teacher should guide students to distinguish the different traditions in naming between the west and east. The comparison teaching of western culture and Chinese culture is effective in raising the students'culture awareness and gaining a deep understanding of culture.

In the text Five Symbols of American Culture of Book Three, students have the chance to learn American culture through the stories of five symbols in America. The vivid explanation of the American culture can be combined with the Chinese culture's explanation, in which the students have more passion and interest.It's an effective method to expand the students'horizon and language knowledge

As international communications increase and deepen, language learners have more chances to get access with western society and culture,feeling the impact of western culture. Therefore, English teacher bear the responsibility to explain the culture knowledge behind the phenomena and direct the students to deal with the relationship between the two cultures appropriately. To learn how to absorb the essence of western culture and abandon the bad part is a challenge for every English teacher. To make the class colorful and active, the effective introduction of general culture knowledge is a key to promote the students cross-national communication ability and the ability to adapt to new culture. It's a significant technique to cultivate students comprehensive quality in the English class.

Fostering of Sense of Responsibility of College English Teacher. 
It's a must for qualified English teachers to have a solid language foundation and good listening, speaking, reading and writing skills. To be specific, teacher should master various, practical teaching methods. He should set a good example for his students in language learning in the class ${ }^{[7]}$. Teacher should process professional spirit, strengthen his cultural quality constantly, and improve his overall professional level. For college English teacher, it's significant to consider the cognitive factors in the teaching process as well as affection factors. The full attention must be attached to the affection factors, so the positive function can be played; and the teaching goals can be reached, the links in the teaching process can be improved, the teaching effect can be optimized, the students qualities can be developed in an all-round way[8]. Teacher being persuasive and patient, students will find class funny and high effective. It's unavoidable to teach language with some ideas from the west[9].it's an useful way to assist the students to learn English better with background information of culture, other than stuffing the western value and beliefs into the students.

Cultural factor plays an important role in the foreign language teaching, cultural education and foreign language teaching is inseparable. English teachers should be bold in exploiting and practice culture teaching, making full use of the rich resources outside the teaching material. It's the teacher's duty to cultivate the students' cross-national communication ability through the introduction of western culture and the organic integration of language points and cultural knowledge.

College English teacher should realize that passing knowledge is as important as passing culture.A good teacher is not only a teacher of language but also a teacher of culture[10].Language teacher is required to be good at mother country's culture when studying the other country's culture. The culture consciousness of the teacher would help them to obtain a better understanding of the text from different aspects. The teacher's attitude and explanation of the western culture impact the students greatly. So English teacher should fulfill the duty of spreading western culture and raising the culture awareness of students, guiding students to learn western culture and absorb Chinese culture, fostering students' national identity and broad cultural sense to learn more about the world.

It needs the encouragement from the general environment and self-study of individual to cultivate the college English teacher's sense of responsibility. The direction of the authority is of importance in developing teachers, esp useful in strengthening teacher's quality. The cultivation of multicultural consciousness is required in modern language learning, in which the teacher's humanistic quality is significant. College English teacher should bear the rich humanistic spirit,loving life and work with sensitive perception for good things in life, thus, influence students in a positive way. Among colleagues, English teachers can learn from each other and communicate frequently, constructing a good foreign language learning environment with a strong humanism.

\section{Reference}

[1] Chengmiao Hao. The Pedagogy Perspective of College English[J], China's School Education, 2009.08

[2] Tian Liang ,Ning Yan. Emotional Teaching Analysis of College English Autonomous Learning[J], Journal of Yangtze University,2011.05.

[3] Shutang Zhen, New Horizon College English[M]. Beijing: Foreign Language Teaching and Research Press, 2008: i

[4] Lihong Zhao. The Application of Emotional Teaching in College English Teaching Trial Analysis[J], Educational Management,2015.05.

[5] Song Wu. Education and Culture[J], Higher Education Research,2002.11

[6] Donald \&Ballinger, Aspects of Language[M], London Press,1981

[7] Barrow .R.Culture, Values and Language Classroom[M],Modern English Publications and the British Council,1990) 